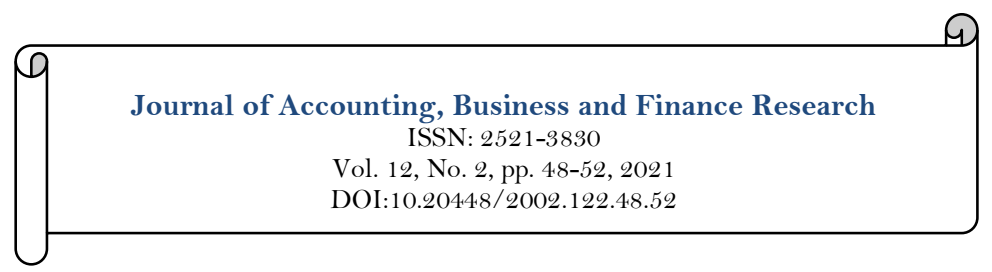

\title{
The Study of Factors that Influence Organizational Performance: Evidence from Companies in the Lower Northern Region of Thailand
}

\author{
Nuatip Sumkaew ${ }^{1 *}$ \\ Ruankwan Intanon ${ }^{2}$ \\ 1.2 Accounting Department, Faculty of Business Economics and Communications, Naresuan University, Phitsanulok, Thailand. \\ ${ }^{2}$ Email:nuatips@,nu.ac.th
}

\begin{tabular}{|c|c|}
\hline Abstract & \\
\hline $\begin{array}{l}\text { A dynamic business environment focuses on corporate profit and } \\
\text { performance. Consequently, managers need strategically relevant } \\
\text { information to formulate and implement business strategies in order } \\
\text { to achieve business growth and survive in an uncertain economic } \\
\text { environment. The purpose of this study is to examine the interaction } \\
\text { effects of environmental uncertainty and strategic management } \\
\text { accounting (SMA) on organizational performance. The } \\
\text { configurations are derived from a sample of } 166 \text { medium and large } \\
\text { firms in the lower northern region of Thailand. A quantitative } \\
\text { method is used for data collection through a survey design approach } \\
\text { using a questionnaire. Contingency theory is employed in this study. } \\
\text { The results indicate that a fit between environmental uncertainty } \\
\text { and strategic management accounting has a positive, direct } \\
\text { relationship with organizational performance. Moreover, a higher } \\
\text { level of environmental uncertainty will improve organizational } \\
\text { performance. As previous studies have not fully addressed the } \\
\text { interactive linkage, this study provides evidence of how key factors } \\
\text { can interact to promote organizational performance. }\end{array}$ & $\begin{array}{l}\text { Keywords: } \\
\text { Environmental uncertainty } \\
\text { Strategic management accounting } \\
\text { Organizational performance } \\
\text { Thailand. } \\
\text { JEL Classification: } \\
\text { D80; L25; L69; M49. } \\
\text { Licensed: } \\
\text { This work is licensed under a } \\
\text { Creative Commons Attribution } 4.0 \\
\text { License. } \\
\text { Publisher: } \\
\text { Scientific Publishing Institute } \\
\text { Received: } 24 \text { May } 2021 \\
\text { Revised: } 28 \text { June } 2021 \\
\text { Accepted: } 19 \text { July } 2021 \\
\text { Published: } 6 \text { August } 2021 \\
\\
\text { ( Corresponding Author) }\end{array}$ \\
\hline
\end{tabular}

Funding: This study received no specific financial support.

Competing Interests: The authors declare that they have no competing interests.

\section{Introduction}

Business environments have rapidly changed and become increasingly sophisticated. Organizations have to adapt and employ innovation tools to ensure quality management, cost efficiency, eco-efficiency, and strategic decision making (Bisbe \& Malagueño, 2012; Soheilirad \& Sofian, 2016). Managers develop strategic management accounting (SMA) techniques and shift the focus from operational information to a more strategic orientation to facilitate decision making and improve organizational performance (Agbejule, 2005; Fleming, Chow, \& Chen, 2009). Guilding, Cravens, and Tayles (2000) identified the specific criteria of SMA techniques from a strategic aspect. The techniques illustrate the environmental perspective and long-term future-oriented timeframes of organizations. Prior studies suggest that SMA techniques have been widely adopted by organizations in several developed countries, such as the United Kingdom, the United States, and Sweden (Ax \& Greve, 2017; Pavlatos \& Kostakis, 2015). In developing countries, the status of SMA technique adoption and the impacts of contingent factors are inconclusive (Rashid, Ali, \& Hossain, 2021). Thailand is one of the developing countries (Lim, 1997) dominated by agriculture and new industrial economy. Thai managers primarily use and rely on information from traditional management accounting techniques. Managers now demand more stringent financial reporting and disclosure requirements, and the information from innovative 
management accounting techniques provides more relevant data for decision making. The information from SMA also helps managers to make optimal decisions, especially in times of crisis, and improve organizational performance (Cadez \& Guilding, 2008; Chongruksut \& Brooks, 2005). There is little evidence of the interaction effects of SMA information usage and environmental uncertainty on organizational performance in developing countries such as Thailand, so this study seeks to contribute to the existing knowledge on the variations between SMA information usage, environmental uncertainty, and organizational performance.

\section{Theoretical Framework and Hypothesis Development}

The concept of strategic management accounting (SMA) was first published in a management accounting magazine. Simmonds (1981) stated that SMA includes the provision of competitor data analysis in the development and monitoring of corporate strategy. There is empirical evidence of the extent of adoption and/or perceived benefits from SMA techniques and the impact of SMA adoption on organizational performance in several countries (Cadez \& Guilding, 2007; Guilding et al., 2000). SMA information plays an important role for decision makers to facilitate organizational performance. However, the uncertainty of the business environment can lead to fluctuations in organizational performance (Fleming et al., 2009).

Cadez and Guilding (2012) investigated the relationship between SMA and organizational performance in the largest Slovenian manufacturing companies. The results revealed that organizational performance is promoted when accountants are highly involved in the use of SMA information, which is in line with developments in the modern business environment. SMA information is a key to value maximization (managerial performance) because the quality of decisions is determined by the quality of information available to the decision maker (Agbejule, 2005). The intensity of market competition and high environmental uncertainty put pressure on accountants to add value to the strategic decision-making process. Therefore, accountants will develop a greater appreciation for the justifiability of the expenditure of resources by using SMA information. Cadez and Guilding (2008) applied a structural equation model to examine the mediating effect of the use of SMA and the accountant's involvement in the strategic decision-making process on firm performance. They pointed out that SMA techniques are not necessarily related to organizational performance but that organizational performance is a product of an appropriate match between environmental uncertainty and SMA usage. A case study by Ma and Tayles (2009) showed a prolonged series of increasing use of strategic management information for strategic decision making. For example, management accounting reports shifted from rolling forecasts and decision tools to management issues and attention to future performance improvement rather than routing reporting. This occurred after the introduction of SMA. In addition, SMA offered very appealing solutions to increase accountability for external competitive pressures that place strong demands on the efficient conduct of commercial activities.

In contrast, previous evidence has shown that neither the environmental uncertainty factor nor the use of SMA information had a positive impact on organizational performance. Yongvanich and Guthrie (2009) investigated the relationship between SMA and organizational performance in organizations listed on the Stock Exchange of Thailand and found no relationship between them. Organizational performance can be favored by various factors (Ax \& Greve, 2017). Bisbe and Malagueño (2012) investigated how SMA influences organizational performance through the shaping of strategies in medium and large Spanish organizations. The results indicated that SMA and organizational performance have a negative association when environmental dynamics are low, but not when environmental dynamics are high.

Therefore, we expect a pattern of mediation such that:

$H_{0:}$ There is no interaction effect between environmental uncertainty and strategic management accounting information on organizational performance.

$H_{I}$ : There is an interaction effect between environmental uncertainty and strategic management accounting information on organizational performance.

\section{Data and Research Design}

In this study, the questionnaire survey used by Hyvönen (2007); Köseoglu, Topaloglu, Parnell, and Lester (2013) and Maiga, Nilsson, and Jacobs (2014) is used for data collection. The item-objective congruence was used to assess content validity. The items of the questionnaire were adapted independently from the recommendations of experts, three academics and three directors. A pilot questionnaire was distributed to 30 companies that were excluded from the target sample. The population consisted of 402 medium and large companies taken from the database of the Department of Business Development in Thailand. The sample companies were randomly selected from the technology, resources, finance, manufacturing, food and beverage, service, and construction industries. The questionnaires were pre-coded to identify non-respondents for later pairing and follow-up purposes. A total of 166 completed questionnaires were returned, giving a final response rate of $41.29 \%$. A response rate greater than $25 \%$ is generally accepted in accounting research (Smith, 2003; Smith, Abdullah, \& Abdul Razak, 2008). The returned questionnaires were tested for non-response bias using t-tests to compare the mean scores of the first ten and last ten responses. There were no statistically significant differences between the early and late groups, confirming the assumption of non-response bias. Demographic data are presented in Table 1. 


\begin{tabular}{|c|c|c|}
\hline & Number & $\%$ \\
\hline \multicolumn{3}{|l|}{ Position at work } \\
\hline Chief financial officer & 27 & 16.26 \\
\hline Accounting manager & 106 & 63.86 \\
\hline Accounting supervisor & 33 & 19.88 \\
\hline \multicolumn{3}{|l|}{ Years of working in the position } \\
\hline Less than 5 years & 66 & 39.76 \\
\hline $6-10$ Years & 72 & 43.37 \\
\hline More than 10 years & 28 & 16.87 \\
\hline \multicolumn{3}{|l|}{ Educational background } \\
\hline Doctoral degree & 3 & 1.81 \\
\hline Master's degree & 23 & 13.85 \\
\hline Bachelor's degree & 140 & 84.34 \\
\hline \multicolumn{3}{|l|}{ Industry category } \\
\hline Technology & 21 & 12.65 \\
\hline Services & 61 & 36.75 \\
\hline Industrials & 18 & 10.84 \\
\hline Property and construction & 16 & 9.64 \\
\hline Agro and agriculture industries & 32 & 19.28 \\
\hline Consumer products & 2 & 1.20 \\
\hline Resources and others & 16 & 9.64 \\
\hline
\end{tabular}

\subsection{Variable Measurement}

The variables used to test the hypotheses are environmental uncertainty, strategic management accounting and organizational performance. Factor analysis is used to select the items for the questions to measure each group of variables. A five-point Likert scale, a type of psychometric response scale, was employed. The respondents were asked to indicate their level of agreement to each questionnaire item, from one (strongly disagree) to five (strongly agree). The sources of the variables and the reliability analysis results using Cronbach's Alpha coefficients are presented in Table 2.

The descriptive statistics are as follows: environmental uncertainty (mean = 3.421, S.D. $=0.849$ ), organizational performance $($ mean $=3.199$, S.D. $=0.633)$, and SMA information usage $($ mean $=2.913$, S.D. $=$ $0.941)$.

Table 2. Variables, sources of questionnaire items, and Cronbach's Alpha values.

\begin{tabular}{l|l|c|c}
\hline Variable & Sources of questionnaire items & $\begin{array}{c}\text { Number of items } \\
\text { Cronbach's alpha } \\
\text { value }\end{array}$ & 0.934 \\
\hline Environmental uncertainty & $\begin{array}{l}\text { Agbejule (2005) } \\
\text { Adebayo and Ashley (2007) }\end{array}$ & 8 & 16 \\
\hline $\begin{array}{l}\text { Strategic management accounting } \\
\text { Strategic decision making) }\end{array}$ & Cadez and Guilding (2008) & 4.976 \\
\hline $\begin{array}{l}\text { Financial performance of } \\
\text { organizations }\end{array}$ & $\begin{array}{l}\text { Agbejule (2005) } \\
\text { Soheilirad and Sofian (2016) }\end{array}$ & 0.880 \\
\hline
\end{tabular}

\section{Results and Discussions}

This study aims to investigate the relationships among environmental uncertainty (EU), strategic management accounting (SMA) and organizational performance (OP). Pearson's correlation matrix for these variables is shown in Table 3. The results of the correlation analysis indicate that environmental uncertainty has a significant positive correlation with the performance of organizations.

\begin{tabular}{l|c|c|c} 
Table 3. Pearson's correlation among environmental uncertainty, strategic management accounting, and performance of organizations. \\
\hline Variable & $\begin{array}{c}\text { Organizational } \\
\text { performance }\end{array}$ & $\begin{array}{c}\text { Environmental } \\
\text { uncertainty }\end{array}$ & $\begin{array}{c}\text { Strategic management } \\
\text { accounting }\end{array}$ \\
\hline Organizational performance & 1 & $0.296^{* *}$ & 0.220 \\
\hline Environmental uncertainty & $0.296^{* *}$ & 1 & 0.487 \\
\hline Strategic management accounting & 0.220 & 0.487 & 1 \\
\hline
\end{tabular}

The hypothesis is tested using the equation: $\mathrm{Y}_{\mathrm{i}}=b_{0}+b_{1} \mathrm{EU}_{\mathrm{i}}+b_{2} \mathrm{SMA}_{\mathrm{i}}+b_{3}\left(\mathrm{EU}_{\mathrm{i}} \mathrm{x} \mathrm{SMA}_{\mathrm{i}}\right)+e_{\mathrm{i}}$,

Where:

$\mathrm{Y}_{\mathrm{i}}$ is the performance of the $i$ th organization.

$\mathrm{EU}_{\mathrm{i}}$ is the level of perceived environmental uncertainty of the $i$ th organization. 
$\mathrm{SMA}_{\mathrm{i}}$ is the level of perceived benefit from strategic management accounting information of the $i$ th organization.

$\mathrm{EU}_{\mathrm{i}} \mathrm{x} \mathrm{SMA}_{\mathrm{i}}$ is the interaction term.

$e_{\mathrm{i}}$ is the error term.

Table 4. Two-way regression results for the performance of organizations.

\begin{tabular}{c|c|c|c}
\multicolumn{5}{|c}{ Table 4. Two-way regression results for the performance of organizations. } \\
\hline & Unstandardized regression coefficient & t-value & p-value \\
\hline Constant & 0.054 & 2.218 & 0.113 \\
\hline EU & 0.770 & 37.744 & 0.000 \\
\hline SMA & -0.285 & -12.897 & 0.001 \\
\hline EU x SMA & -0.570 & -14.711 & 0.001 \\
\hline Adjusted R & 0.996 & & \\
\hline F & 504.585 & & \\
\hline P & 0.000 & & \\
\hline $\mathrm{N}$ & 166 & & \\
\hline
\end{tabular}

Table 4 presents the results of the hypothesis tests. The model shows an adjusted R-squared of $99.6 \%$, and $\mathrm{b}_{1}$ is positive and significant $(\mathrm{t}=37.744, \mathrm{p}=0.000)$, whereas $\mathrm{b}_{2}$ and $\mathrm{b}_{3}$ are negative and significant $(\mathrm{t}=-$ $12.897, \mathrm{p}=0.001$ and $\mathrm{t}=-14.711, \mathrm{p}=0.001$, respectively). There are three main findings in this study. First, the results show that there is a positive significant relationship between environmental uncertainty and organizational performance. In line with Agbejule (2005), the higher the level of environmental uncertainty, the more positive the impact on financial performance is. An increase in environmental uncertainty leads to demand for the use of innovative tools and SMA information to support decision making. Second, the results show that strategic management accounting information has a negative impact on financial performance. Earlier evidence also suggested that when the SMA information processing capacity doesn't meet the manager's needs, the resulting decisions will be flawed or late, leading to suboptimal performance (Gupta, 1987). Although Thai managers working in large manufacturing organizations prefer to use SMA information for decision making, lack of employee skills/training, lack of consultants, and no significant problems with conventional management accounting techniques are the main obstacles that prevent the improvement of organizational performance (Suranatthakul, Dokmaithong, Intanon, Phetruen, \& Sumkaew, 2020). Pavlatos and Kostakis (2015) argued that organizations that implement and use SMA tools can be more effective in tracking their competitors' operations, costs, customers, and performance. SMA tools are able to provide organizations with better information related to competitors, customers and profitability per industry group and consequently improve organizational performance. Finally, the results also show that the relationship between environmental uncertainty and strategic management accounting information has a negative significant impact on organizational performance. The study by Lillis (2002) reported that SMA tools focus on customer responsiveness and involve adaptation strategies rather than quality. When the intensity of business environment uncertainty is high, managers anticipate and measure the impact of quality on performance to a greater extent than customer responsiveness. Managers found that these measures were difficult to use and did not enhance organizational performance. The results are contrary to those of Soheilirad and Sofian (2016), who found that environmental uncertainty has an influence on organizational performance and is a driver of sustainable competitive advantage. Information from SMA, which concentrates on the consumer value generated relative to competitors, helps in monitoring organizational performance in the business environment using an overall strategic plan. Consequently, managers operating in uncertain environments need to be alert to any changes in their environment. They will request effective SMA information for decision making and try to improve organizational profitability (Agbejule, 2005).

\section{Conclusions and Limitations}

Little research has been conducted on the interaction effect of SMA information and environmental uncertainty on performance in organizations in the lower northern region of Thailand. This study examined the mediating role of strategic management accounting information in relation to organizational performance. The findings support the study by Lillis (2002), who stated that SMA information does not help to enhance organizational performance in an uncertain business environment.

This study is limited to a sample of medium and large organizations located in one region of a country. Future research should therefore examine other samples, such as small organizations or organizations located in other regions.

\section{References}

Adebayo, A., \& Ashley, B. (2007). Perceived environmental uncertainty, supply chain purchasing strategy, and use of MAS information: An empirical study of Finnish firms. Managerial Auditing Journal, 22(9), 913-927. https://doi.org/10.1108/02686900710829417 
Agbejule, A. (2005). The relationship between management accounting systems and perceived environmental uncertainty on managerial performance: A research note. Accounting and Business Research, 35(4), 295-305. https://doi.org/10.1080/00014788.2005.9729996

Ax, C., \& Greve, J. (2017). Adoption of management accounting innovations: Organizational culture compatibility and perceived outcomes. Management Accounting Research, 34, 59-74. https://doi.org/10.1016/j.mar.2016.07.007

Bisbe, J., \& Malagueño, R. (2012). Using strategic performance measurement systems for strategy formulation: Does it work in dynamic environments? Management Accounting Research, 23(4), $296-311$. https://doi.org/10.1016/j.mar.2012.05.002

Cadez, S., \& Guilding, C. (2008). An exploratory investigation of an integrated contingency model of strategic management accounting. Accounting, Organizations and Society, 33(7-8), 836-863. https://doi.org/10.1016/j.aos.2008.01.003

Cadez, S., \& Guilding, C. (2007). Benchmarking the incidence of strategic management accounting in Slovenia. Journal of Accounting \& Organizational Change, 3(2), 126-146. https://doi.org/10.1108/18325910710756140

Cadez, S., \& Guilding, C. (2012). Strategy, strategic management accounting and performance: A configurational analysis. Industrial Management \& Data Systems, $112(3)$, 484-501.

Chongruksut, W., \& Brooks, A. (2005). The adoption and implementation of activity-based costing in Thailand. Asian Review of Accounting, 13(2), 1-17. https://doi.org/10.1108/eb060784

Fleming, D. M., Chow, C. W., \& Chen, G. (2009). Strategy, performance-measurement systems, and performance: A study of Chinese firms. The International Journal of Accounting, 44(3), 256-278. https://doi.org/10.1016/j.intacc.2009.06.004

Guilding, C., Cravens, K. S., \& Tayles, M. (2000). An international comparison of strategic management accounting practices. Management Accounting Research, 11(1), 113-135. https://doi.org/10.1006/mare.1999.0120

Gupta, A. K. (1987). SBU strategies, corporate-SBU relations, and SBU effectiveness in strategy implementation. Academy of Management Journal, 30(3), 477-500. https://doi.org/10.2307/256010

Hyvönen, J. (2007). Strategy, performance measurement techniques and information technology of the firm and their links to organizational performance. Management Accounting Research, 18(3), 343-366. https://doi.org/10.1016/j.mar.2007.02.001

Köseoglu., M. A., Topaloglu, C., Parnell, J. A., \& Lester, D. L. (2013). Linkages among business strategy, uncertainty and performance in the hospitality industry: Evidence from an emerging economy. International Journal of Hospitality Management, 34, 81-91. https://doi.org/10.1016/j.ijhm.2013.03.001

Lillis, A. M. (2002). Managing multiple dimensions of manufacturing performance - an exploratory study. Accounting, Organizations and Society, 27(6), 497-529. https://doi.org/10.1016/s0361-3682(01)00032-0

Lim, D. (1997). Economic significance of pacific Asia Region in the world economy. In R. Ma (ed.), Financial Reporting in the Pacific Asia Region. Singapore: World Scientific Publishing.

Ma, Y., \& Tayles, M. (2009). On the emergence of strategic management accounting: An institutional perspective. Accounting and Business Research, 39(5), 473-495. https://doi.org/10.1080/00014788.2009.9663379

Maiga., A. S., Nilsson, A., \& Jacobs, F. A. (2014). Assessing the impact of budgetary participation on budgetary outcomes: The role of information technology for enhanced communication and activity-based costing. Journal of Management Control, 25(1), 5-32. https://doi.org/10.1007/s00187-014-0191-9

Pavlatos, O., \& Kostakis, H. (2015). Management accounting practices before and during economic crisis: Evidence from Greece. Advances in Accounting, 31(1), 150-164. https://doi.org/10.1016/j.adiac.2015.03.016

Rashid, M. M., Ali, M. M., \& Hossain, D. M. (2021). Strategic management accounting practices: A literature review and opportunity for future research. Asian Journal of Accounting Research, 6(1), 109-132. https://doi.org/10.1 108/ajar06-2019-005

Simmonds, K. (1981). Strategic management accounting. Management Accounting, 59, 9-26.

Smith, M. (2003). Research methods in accounting. London: SAGE.

Smith, M., Abdullah, Z., \& Abdul Razak, R. (2008). The diffusion of technological and management accounting innovation: Malaysian evidence. Asian Review of Accounting, 16(3), 197-218. https://doi.org/10.1 108/13217340810906672

Soheilirad, S., \& Sofian, S. (2016). A proposed model of the mediating effect of strategic management accounting on the relationship between perceived environmental uncertainty and firm performance. International Journal of Research-Granthaalayah, 4(1), 231-239. https://doi.org/10.29121/granthaalayah.v4.11.2016.2869

Suranatthakul, K., Dokmaithong, S., Intanon, R., Phetruen, W., \& Sumkaew, N. (2020). Modern management accounting practices for large manufacturing enterprise in lower Northern provinces group I Thailand. Journal of Accounting, Business and Finance Research, 9(1), 24-28.

Yongvanich, K., \& Guthrie, J. (2009). Balanced scorecard practices amongst Thai companies: Performance effects. Pacific Accounting Review, 21(2), 132-149. https://doi.org/10.1108/01140580911002062 